\title{
Growth inhibitory properties of extracts prepared from selected Leptospermum and Melaleuca species against a panel of pathogenic bacteria
}

\author{
Lindiwe Nomathemba Mpala' ${ }^{1}$, Getmore Rumbudzai Chikowe' ${ }^{1}$ Ian Edwin Cock ${ }^{1,2^{*}}$ \\ 'School of Natural Sciences, Griffith University, 170 Kessels Rd, Nathan, Brisbane, Queensland 4111, AUSTRALIA. \\ 'Environmental Futures Research Institute, Griffith University, 170 Kessels Rd, Nathan, Brisbane, Queensland 4111, AUSTRALIA.
}

\begin{abstract}
Introduction: Leptospermum longifolium (C.T. White \& W.D. Francis) S.T. Blake, Leptospermum petersonii Bailey and Melaleuca alternifolia (Maiden \& Betche) Cheel are aromatic native Australian trees with uses as traditional medicines. Essential oils produced from leaves of these species have reputed antiseptic properties against many bacteria. Despite this, L. longifolium, L. petersonii and M. alternifolia leaf solvent extractions have not been rigorously examined for antibacterial properties against many pathogens. Methods: The antimicrobial activity of methanolic L. Iongifolium, $L$. petersonii and $M$. alternifolia leaf extracts was investigated by disc diffusion and growth time course assays against a panel of pathogenic bacteria. The growth inhibitory activity was quantified by MIC determination. Toxicity was determined using the Artemia franciscana nauplii bioassay. Results: The methanolic L. longifolium, L. petersonii and M. alternifolia leaf extracts inhibited the growth of a wide range of bacterial species. Growth of both gram positive and gram negative bacteria was inhibited by all extracts. The $L$. longifolium and $L$. petersonii extracts were generally more potent inhibitors of bacterial growth than was the $M$. alternifolia extract against most bacterial species. A. hydrophilia, C. freundi, P. mirabilis and B. cereus growth was particularly susceptible to the extracts, with MIC values as low as $147 \mu \mathrm{g} / \mathrm{mL}$ (inhibition of $A$. hydrophilia growth by the $L$. Iongifolium extract). The antibacterial activity of the $L$. Iongifolium, $L$. petersonii and
\end{abstract}

M. alternifolia extracts were further investigated by growth time course assays, with significant growth inhibition recorded in all cultures within $1 \mathrm{~h}$ of exposure. All extracts were determined to be nontoxic in the Artemia franciscana nauplii bioassay, indicating their safety for therapeutic uses. Conclusions: The lack of toxicity of the methanolic L. Iongifolium, L. petersonii and $M$. alternifolia leaf extracts and their growth inhibitory bioactivity against a panel of pathogenic bacteria partially validate Australian Aboriginal usage of these species as antiseptic agents and indicate their potential in the development of antiseptic agents.

Key words: Myrtaceae, Leptospermum longifolium, Leptospermum petersonii, Melaleuca alternifolia, Tea-tree, Australian plants, Antibacterial activity, Medicinal plants.

\section{Correspondence:}

lan Edwin Cock, School of Natural Sciences, Griffith University, 170 Kessels Rd, Nathan, Brisbane, Queensland 4111, AUSTRALIA. Phone no: +61 737357637 ; Fax: +61 737355282

E-mail: I.Cock@griffith.edu.au (I. E. Cock)

DOI : $10.5530 / p c .2016 .4 .4$

\section{INTRODUCTION}

Plants produce a wide variety of secondary metabolites which provide characteristic pigment, odour and flavour characteristics. In addition, these compounds may also provide the plants with protection against microbial challenge. ${ }^{1}$ Traditional plant derived medicines have been used for thousands of years in most parts of the world and with the increase in microbial antibiotic resistance, their use in fighting bacterial pathogens is becoming the focus of intense study. ${ }^{2,3}$ Whilst much of the research into traditional medicinal plant use has focused on Asian, ${ }^{4}$ African ${ }^{5}$ and South American ${ }^{6}$ plants, the therapeutic potential of the flora of Australia has also been recognised for thousands of years. The first Australians had well developed ethnopharmacological systems and understood the therapeutic properties of a wide variety of aromatic Australian plants.? Despite this, relatively few studies have rigorously examined the antibacterial activity of Australian native plants. However, recently there has been increased study in this field.

The healing properties of Australian plants of the family Myrtaceae have been understood by Australian Aborigines for many thousands of years. The genuses Leptospermum and Melaleuca are particularly prevalent in traditional Aboriginal healing systems. ${ }^{7}$ More recently, Sir Joseph Banks (the botanist aboard Captain James Cook's voyage of the Endeavour) coined the phrase 'tea-tree' for the endemic Australian plant Melaleuca alternifolia due to similarities in use with Camellia sinensis, and some of its perceived therapeutic properties. ${ }^{7}$ However, this common name creates some taxonomic confusion, with several Leptospermum and
Kunzea species also collectively known as 'tea-tree'. Nowadays, a thriving trade exists, with 'tea tree' essential oils marketed globally as an antiseptic. The bacterial growth inhibitory properties of many genera within the family Myrtaceae have been documented. In particular, Callistemon spp. ${ }^{8}$ Eugenia spp., ${ }^{7}$ Kunzea spp. ${ }^{7,9}$ Leptospermum spp. ${ }^{7,10,11}$ and Syzygium spp. ${ }^{12-14}$ have been reported to inhibit the growth of a wide panel of bacteria, including many medicinally important pathogens. It is noteworthy that many of these studies have screened essential oils for antibacterial activity and the growth inhibitory properties of several Myrtaceae extracts are yet to be rigorously examined.

Leptospermum longifolium (C.T. White \& W.D. Francis) S.T. Blake (Figure 1a) and Leptospermum petersonii Bailey (Figure 1b) are large shrubs/small trees which are native to sclerophyll forests and subtropical rainforest areas of eastern Australia. Melaleuca alternifolia (Maiden \& Betche) Cheel (commonly known as narrow leaved paperbark, narrow leaved tea-tree; Figure 1c) is a related species which has a similar but limited occurrence in eastern Australian subtropical sclerophyll forests, particularly besides streams and in swampy areas. ${ }^{1}$ The leaves of all 3 species are distilled commercially to produce essential oils rich in geraniol (Figure 1d), neral (Figure 1e), citronellal (Figure 1f), pinene (Figure 1g), sabinene (Figure 1h), a-terpinene (Figure 1i), limonene (Figure 1j) and $1,8$-cineole (Figure $1 \mathrm{k})^{?}$

Most studies into the antibacterial potential of the family Myrtaceae focus on the essential oil of the leaves. ${ }^{7,15,16}$ In most Leptospermum and 
Melaleuca species, the levels and composition of the essential oil terpenoid components receives the most interest. In particular, the monoterpenoid compositions of several species have been extensively reported.' Leptospermum spp. essential oils contain especially high levels of citral, which comprises a mixture of geranial ( $\beta$-citral; Figure 1d) and neral ( $\alpha$-citral; Figure 1e) ${ }^{7,15,16}$ Both neral and geranial have been previously reported to have potent antibacterial activity against a variety of bacteria. ${ }^{17-19}$ Similarly, a high composition of other monoterpenoids in various Myrtaceae essential oils has been reported, with citronellal (Figure 1f), pinene (Figure 1g), sabinene (Figure 1h), a-terpinene (Figure 1i), limonene (Figure $1 \mathrm{j}$ ) and 1,8-cineole (Figure 1k) often reported as major components. The antiseptic properties of these compounds is well established, with potent bacteriostatic and bactericidal activities reported. ${ }^{22}$

Most of the studies reporting antibacterial properties for Leptospermum spp. and Melaleuca spp. have examined essential oils. However, the use of essential oils for the testing of antimicrobial activity can be problematic. The relative insolubility of many of the oil components retards their diffusion through agar gels in agar dilution or disc diffusion studies. Many studies have utilised solubilising agents (e.g. Tween 80 ) to aid oil component diffusion, resulting in variable results. ${ }^{20,21}$ Solubilising agents appear to increase the susceptibility of some bacteria to antimicrobial agents, decrease the susceptibility of others, whilst having no effect on yet other bacteria. The current study was undertaken to examine 3 taxonomically related Myrtaceae spp. (L. longifolium, L. petersonii and M. alternifolia) for growth inhibitory properties against a panel of pathogenic bacteria.

\section{MATERIALS AND METHODS}

\section{Plant collection and extraction}

Leptospermum longifolium (C.T. White \& W.D. Francis) S.T. Blake, Leptospermum petersonii Bailey and Melaleuca alternifolia (Maiden \& Betche) Cheel leaves were obtained from and identified by Philip Cameron, senior botanic officer, Mt Cootha Botanical Gardens, Brisbane, Australia. Leaf samples were dried in a Sunbeam food dehydrator and stored at $-30^{\circ} \mathrm{C}$. Prior to use, the leaves were freshly ground to a coarse powder and $1 \mathrm{~g}$ quantities were weighed into separate tubes. A volume of $50 \mathrm{~mL}$ methanol (Ajax, Australia; AR grade) was added to individual tubes and extracted for $24 \mathrm{hrs}$ at $4^{\circ} \mathrm{C}$ with gentle shaking. The extracts was filtered through filter paper (Whatman No. 54) under vacuum, followed by drying by rotary evaporation in an Eppendorf concentrator 5301. The resultant pellets were dissolved in $10 \mathrm{~mL}$ sterile deionised water (containing 1\% DMSO). The extracts were passed through a $0.22 \mu \mathrm{m}$ filter (Sarstedt) and stored at $4^{\circ} \mathrm{C}$ until use.

\section{Qualitative phytochemical studies}

Phytochemical analysis of the $L$. longifolium, L. petersonii and $M$. alternifolia leaf extracts for the presence of saponins, phenolic compounds, flavonoids, phytosteroids, triterpenoids, cardiac glycosides, anthraquinones, tannins and alkaloids was conducted by previously described assays. ${ }^{23-24}$

\section{Antibacterial screening \\ Test microorganisms}

All media was supplied by Oxoid Ltd., Australia. Clinical isolate microbial strains of Aeromonas hydrophilia, Alcaligenes feacalis, Bacillus cereus, Citrobacter freundii, Escherichia coli, Klebsiella pneumoniae, Proteus mirabilis, Pseudomonas fluorescens, Salmonella newport, Serratia marcescens, Shigella sonneii, Staphylococcus aureus, Staphylococcus epidermidis and Streptococcus pyonenes were obtained from Ms Michelle Mendell and Ms Jane Gifkins, Griffith University. All stock cultures were subcultured and maintained in nutrient broth at $4^{\circ} \mathrm{C}$.

\section{Evaluation of antimicrobial activity}

Antimicrobial activity of all plant extracts was determined using a modified disc diffusion assay. ${ }^{25-27}$ Briefly, $100 \mu \mathrm{L}$ of each bacterial culture was grown in $10 \mathrm{~mL}$ of fresh nutrient broth until they reached a count of $\sim 10^{8}$ cells $/ \mathrm{mL}$. A volume of $100 \mu \mathrm{L}$ of the bacterial suspension was spread onto nutrient agar plates and extracts were tested for antibacterial activity using $5 \mathrm{~mm}$ sterilised filter paper discs. Discs were infused with $10 \mu \mathrm{L}$ of the plant extracts, allowed to dry and placed onto the inoculated plates. The plates were allowed to stand at $4^{\circ} \mathrm{C}$ for $2 \mathrm{~h}$ before incubation at $30^{\circ} \mathrm{C}$ for $24 \mathrm{~h}$. The diameters of the inhibition zones were measured to the closest whole millimetre. Each assay was performed in at least triplicate. Mean values $( \pm$ SEM) are reported in this study. Standard discs of ampicillin $(10 \mu \mathrm{g})$ were obtained from Oxoid, Australia and were used as positive controls to compare antibacterial activity. Filter discs infused with $10 \mu \mathrm{L}$ of distilled water were used as a negative control.

\section{Minimum inhibitory concentration (MIC) determination}

The minimum inhibitory concentration (MIC) of each extract against susceptible bacteria was determined as previously described. ${ }^{28,29}$ Briefly, the plant extracts were diluted in deionised water and tested across a range of concentrations. Discs were infused with $10 \mu \mathrm{L}$ of the test dilutions, allowed to dry and placed onto inoculated plates. The assay was completed as outlined above and graphs of the zone of inhibition versus concentration were plotted for each extract. Linear regression was used to determine the MIC values of each extract.

\section{Bacterial growth time course assay}

Bacterial growth time course studies were performed as previously described. ${ }^{30}$ Briefly, $3 \mathrm{~mL}$ of the and A. hydrophilia, C. freundi and P. mirabilis bacterial cultures in nutrient broth were added individually to $27 \mathrm{~mL}$ nutrient broth containing $3 \mathrm{~mL}$ of $10 \mathrm{mg} / \mathrm{mL}$ methanolic plant extract to give a final concentration of $1000 \mu \mathrm{g} / \mathrm{mL}$ in the assay. The tubes were incubated at $30^{\circ} \mathrm{C}$ with gentle shaking. The optical density was measured hourly at $550 \mathrm{~nm}$ for a $6 \mathrm{~h}$ incubation period. Control tubes were incubated under the same conditions but without the extract. All assays were performed in triplicate.

\section{Toxicity screening \\ Reference toxin for toxicity screening}

Potassium dichromate $\left(\mathrm{K}_{2} \mathrm{Cr}_{2} \mathrm{O}_{7}\right)$ (AR grade, Chem-Supply, Australia) was prepared as a $4 \mathrm{mg} / \mathrm{mL}$ solution in distilled water and was serially diluted in artificial seawater for use in the Artemia franciscana nauplii bioassay.

\section{Artemia franciscana nauplii toxicity screening}

Toxicity was tested using an adapted Artemia franciscana nauplii lethality assay. ${ }^{31-33}$ Briefly, $400 \mu \mathrm{L}$ of seawater containing approximately 54 (mean 54.2, $\mathrm{n}=75$, SD 11.5) A. franciscana nauplii were added to wells of a 48 well plate and immediately used for bioassay. A volume of $400 \mu \mathrm{L}$ of diluted plant extracts or the reference toxin were transferred to the wells and incubated at $25 \pm 1^{\circ} \mathrm{C}$ under artificial light (1000 Lux). A $400 \mu \mathrm{L}$ seawater negative control was run in triplicate for each plate. All treatments were performed in at least triplicate. The wells were checked at regular intervals and the number of dead counted. The nauplii were considered dead if no movement of the appendages was detected within 10 seconds. After $24 \mathrm{~h}$, all nauplii were sacrificed and counted to determine the total $\%$ mortality per well. The $\mathrm{LC}_{50}$ with $95 \%$ confidence limits for each treatment was determined using probit analysis. 


\section{Statistical analysis}

Data are expressed as the mean \pm SEM of at least three independent experiments. One way ANOVA was used to calculate statistical significance between control and treated groups with a $P$ value $<0.01$ considered to be statistically significant.

\section{RESULTS}

\section{Liquid extraction yields and qualitative phytochemical screening}

Extraction of $1 \mathrm{~g}$ of L. longifolium, L. petersonnii and M. alternifolia leaves with methanol yielded dried extracts ranging from $93 \mathrm{mg}$ (methanolic M. alternifolia extract) to $130 \mathrm{mg}$ (methanolic L. longifolium extract) (Table 1). The dried extracts were resuspended in $10 \mathrm{~mL}$ of deionised water (containing 1\% DMSO), resulting in the extract concentrations shown in Table 1. Qualitative phytochemical studies showed that all extracts contained similar classes of phytochemicals. All had high levels of phenolics and tannins. Generally, all extracts also contained moderate levels of flavonoids and moderate to high levels of saponins. Low to moderate levels of triterpenoids, phytosterols and alkaloids were also present in all extracts. The L. longifolium, L. petersonnii and M. alternifolia extracts were devoid of all other classes of phytochemicals.

\section{Antimicrobial activity}

To determine the growth inhibitory activity of the L. longifolium, L. petersonii and M. alternifolia extracts against the panel of pathogenic bacteria, aliquots $(10 \mu \mathrm{L})$ of each extract were screened in the disc diffusion assay. All extracts inhibited a broad spectrum of the gram negative bacterial species (Figure 2). Indeed, all extracts inhibited the growth of 5 of the 10 gram negative bacteria screened (50\%). The methanolic L. longifolium extract was a potent growth inhibitor against most bacterial species (as assessed by the sizes of the zones of inhibition), with zones of inhibition $>10 \mathrm{~mm}$ against $A$. hydrophilia, C. freundi and P. mirabilis. This inhibition was particularly noteworthy compared to the inhibition by the ampicillin (10 $\mu \mathrm{g}$ : inhibition zones of approximately $8.6,8.3$ and $10.3 \mathrm{~mm}$ respectively against the same bacterial species) and chloramphenicol controls $(2 \mu \mathrm{g}$ : inhibition zones of approximately 9.7, 9.3 and $8.6 \mathrm{~mm}$ respectively against the same bacterial species). The L. longifolium extract was also a good inhibitor of $A$. faecalis and $K$. pneumoniae growth, albeit with smaller zones of inhibition $(<10 \mathrm{~mm})$. Similar bacterial growth inhibitory trends were noted for the L. petersonii and $M$. alternifolia extracts against the gram negative bacterial species (Figure 2). As reported for the L. longifolium extract, the growth of A. faecalis, A. hydrophilia, C. freundi, K. pneumoniae and P. mirabilis was strongly inhibited by the $L$. petersonii and $M$. alternifolia extracts.

The growth of gram positive bacteria was also potently inhibited by the L. longifolium, L. petersonii and M. alternifolia extracts (Figure 3). All of the gram positive bacterial species tested were inhibited by each of the extracts. B. cereus and S. aureus were the most susceptible gram positive bacteria (as judged by the zones of inhibition), with zones of inhibition as large as $10.6 \mathrm{~mm}$ (L. longifolium and L. petersonii inhibition of S. aureus). Noteably, the Leptospermum spp. extracts were substantially more potent inhibitors of gram positive bacterial growth than was the M. alternifolia extract.

The antimicrobial efficacy was further quantified by determining the MIC values for each extract against the microbial species which were determined to be susceptible. All extracts were potent growth inhibitors of several bacterial species (as judged by MIC; Table 2). P. mirabilis was highly susceptible to all of the extracts, with MIC values generally $<500 \mu \mathrm{g} / \mathrm{mL}$ ( $<5 \mu \mathrm{g}$ infused into the disc). As $P$. mirabilis infection is a common cause of urinary tract infections and has also been identified as a trigger of rheumatoid arthritis, ${ }^{38,39}$ the L. longifolium, L. petersonii and $M$. alternifolia leaf extracts have potential for the prevention and treatment of these diseases in genetically susceptible individuals.

The L. longifolium and L. petersonii extracts, but not the M. alternifolia extract, were also potent K. pneumoniae growth inhibitors (MIC's of 320 and $687 \mu \mathrm{g} / \mathrm{mL}$ for the L. longifolium and L. petersonii extracts respectively). As K. pneumoniae can trigger ankylosing spondylitis in genetically susceptible individuals, ${ }^{40,41}$ these extracts may also be useful in the prevention and treatment of this disease. Furthermore, all extracts were moderate inhibitors of $S$. pyogenes growth, with MIC values $1000-1500 \mu \mathrm{g} / \mathrm{mL}$. $S$. pyogenes may cause a myriad of diseases including streptococcal pharyngitis, impetigo and rheumatic heart disease, depending on which tissue it infects. ${ }^{42,43}$ Thus, the methanolic L. longifolium, L. petersonii and M. alternifolia leaf extracts may also be useful in the prevention and treatment of these diseases.

L. longifolium, L. petersonii and M. alternifolia extracts were also good inhibitors of $A$. hydrophilia, with MICs of 147, 279 and $705 \mu \mathrm{g} / \mathrm{mL}$ respectively. The $L$. longifolium and $L$. petersonii extracts, but not the M. alternifolia extract, were also potent inhibitors of C. freundi, B. cereus, S. aureus and S. epidermidis growth, with MIC values substantially $<1000$ $\mu \mathrm{g} / \mathrm{mL}$. The M. alternifolia extract also inhibited the growth of these bacteria, albeit with higher MICs indicative of only moderate growth inhibition.

\section{Bacterial growth time course assay}

The antibacterial activity of the L. longifolium, L. petersonii and M. alternifolia extracts was further investigated in the reference bacterial strains by bacterial growth time course assays in the presence and absence of the extract. As A. hydrophilia, C. freundi, and P. mirabilis were the most susceptible to the L. longifolium, L. petersonii and M. alternifolia extracts, these species were selected for growth time course studies. The starting concentration of the extract used in these assays was $1000 \mu \mathrm{g} / \mathrm{mL}$. All extracts significantly inhibited A. hydrophilia (Figure 4a), C. freundi (Figure $4 \mathrm{~b}$ ) and $P$. mirabilis (Figure $4 \mathrm{c}$ ) growth within $1 \mathrm{~h}$, indicating a rapid antimicrobial action. Furthermore, growth inhibition of all bacterial species by the L. longifolium, L. petersonii and M. alternifolia extracts was still significantly inhibited by the end of the $6 \mathrm{~h}$ time course study. This may indicate that these extracts have bactericidal activity against these bacteria at the doses tested.

\section{Quantification of toxicity}

The toxicity of the L. longifolium, L. petersonii and M. alternifolia extracts was initially tested in the Artemia franciscana nauplii bioassay at a concentration of $2000 \mu \mathrm{g} / \mathrm{mL}$ (Figure 5). All extracts induced low levels of mortality at 24 and $48 \mathrm{~h}$, similar to the $\%$ mortality seen for the seawater control. As none of the extracts induced $>50 \%$ mortality, all were deemed to be nontoxic. Extracts with an $\mathrm{LC}_{50}$ of greater than $1000 \mu \mathrm{g} / \mathrm{mL}$ towards Artemia nauplii have previously been defined as being nontoxic. ${ }^{32}$ In contrast, the potassium dichromate positive controls induced mortality within $4 \mathrm{~h}$ (results not shown), with 100\% mortality induction seen by $24 \mathrm{~h}$.

\section{DISCUSSION}

Plant derived remedies are becoming increasingly sought after in the treatment of a myriad of diseases and disorders due both to their perception of greater safety than synthetic drugs, and the failure of current drug regimens to effectively treat many diseases. Our study examined the ability of methanolic L. longifolium, L. petersonii and M. alternifolia leaf extracts to inhibit the growth of a panel of medicinally important bacterial pathogens, and on their toxicity. The gram positive and gram negative bacteria tested in this study were susceptible to all of 
Table 1: The mass of dried extracted material, the concentration after resuspension in deionised water and qualitative phytochemical screenings of the methanolic L. longifolium, L. petersonii and $M$. alternifolia extracts

\begin{tabular}{|c|c|c|c|c|c|c|c|c|c|c|c|c|c|c|c|c|c|c|c|}
\hline \multirow{2}{*}{ 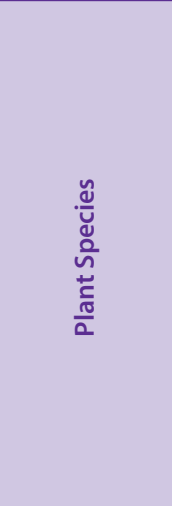 } & \multirow{2}{*}{ 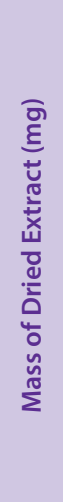 } & \multirow{2}{*}{ 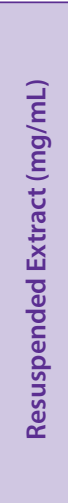 } & \multicolumn{3}{|c|}{$\begin{array}{l}\frac{n}{0} \\
\frac{C}{0} \\
\frac{c}{0}\end{array}$} & 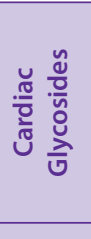 & \multicolumn{2}{|c|}{\begin{tabular}{l}
$\stackrel{n}{c}$ \\
\hdashline 0 \\
$\frac{0}{0}$ \\
$\stackrel{n}{n}$
\end{tabular}} & 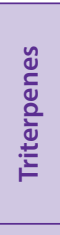 & \multicolumn{2}{|c|}{ 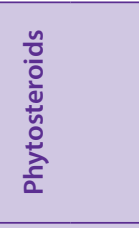 } & \multicolumn{2}{|l|}{$\begin{array}{l}\frac{n}{0} \\
\frac{0}{0} \\
\frac{\check{x}}{\varepsilon}\end{array}$} & \multicolumn{2}{|c|}{$\begin{array}{l}\frac{n}{0} \\
\frac{0}{\circ} \\
\frac{0}{\pi} \\
\frac{\pi}{4} \\
\frac{\pi}{4}\end{array}$} & \multicolumn{2}{|c|}{ 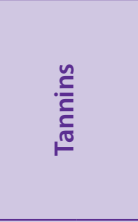 } & \multicolumn{2}{|c|}{ 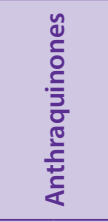 } \\
\hline & & & $\begin{array}{l}\frac{\tilde{O}}{0} \\
\frac{\check{c}}{0} \\
\frac{0}{0} \\
\frac{\pi}{\pi} \\
\stackrel{0}{0}\end{array}$ & $\begin{array}{l}\frac{0}{0} \\
\frac{3}{0} \\
0 \\
\frac{0}{0} \\
\frac{\pi}{3}\end{array}$ & 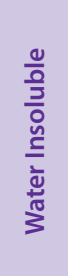 & 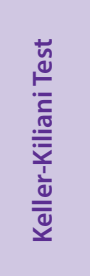 & 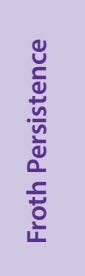 & 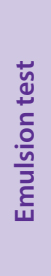 & 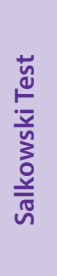 & 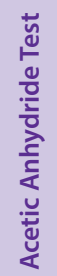 & 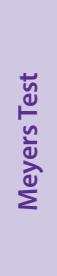 & 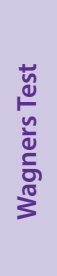 & 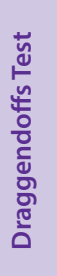 & 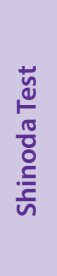 & 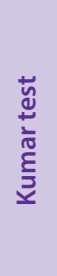 & 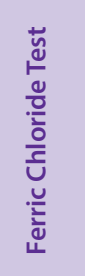 & 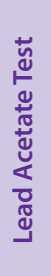 & 巳ัँ & 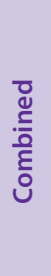 \\
\hline L. longifolium & 130 & 13 & +++ & +++ & +++ & - & +++ & + & - & + & + & + & + & + & + & +++ & + & - & - \\
\hline L. petersonii & 117 & 11.7 & +++ & +++ & +++ & - & + & + & + & + & - & - & - & ++ & ++ & +++ & + & - & - \\
\hline M. alternifolia & 93 & 9.3 & +++ & +++ & +++ & - & +++ & + & + & ++ & ++ & + & + & + & ++ & +++ & + & - & - \\
\hline
\end{tabular}

+++ indicates a large response; ++ indicates a moderate response; + indicates a minor response; - indicates no response in the assay.

Table 2: Minimum bacterial growth inhibitory concentration $(\mu \mathrm{g} / \mathrm{mL})$ of the $L$. longifolium, $L$. petersonii and $M$. alternifolia extracts against susceptible bacterial species

\begin{tabular}{cccc}
\hline $\begin{array}{c}\text { Bacterial species } \\
\text { Gram negative }\end{array}$ & L. longifolium & L. petersonii & M. alternifolia \\
\hline A. faecalis & 1438 & 849 & 2600 \\
A. hydrophilia & 147 & 279 & 705 \\
C. freundi & 619 & 720 & 1350 \\
E. coli & - & - & 815 \\
K.pneumoniae & 320 & 687 & - \\
P. mirabilis & 485 & 648 & 449 \\
P. fluroscens & - & - & - \\
S. newport & - & - & - \\
S. marcenscens & - & - & - \\
S. sonnei & - & - & - \\
Gram positive & & & 1500 \\
B. cereus & 755 & 284 & 2842 \\
S. aureus & 428 & 389 & 2978 \\
S. epidermidis & 978 & 846 & 1486 \\
S. pyogenes & 1230 & 1084 & \\
\hline
\end{tabular}

Numbers indicate the mean MIC values of triplicate determinations. - indicates no inhibition.

the extracts, although a greater susceptibility was noted for gram positive bacterial species. Many previous studies with other plant species have also reported a greater susceptibility of gram positive bacteria towards solvent extracts for South American, ${ }^{34}$ African $^{35}$ and Australian plant extracts. $^{36,37}$

The L. longifolium, L. petersonii and M. alternifolia leaf extracts were particularly potent inhibitors of $P$. mirabilis (MIC values $<500 \mu \mathrm{g} / \mathrm{mL}$ ). As $P$. mirabilis infection is a common cause of urinary tract infections and has also been identified as a trigger of rheumatoid arthritis, ${ }^{38,39}$ the L. longifolium, L. petersonii and M. alternifolia leaf extracts have potential for the prevention of these diseases in genetically susceptible individuals. The L. longifolium and $L$. petersonii extracts were also potent $K$. pneumoniae growth inhibitors. As $K$. pneumoniae can trigger ankylosing spondylitis in genetically susceptible individuals ${ }^{40,41}$ this extract may also be useful in the prevention and treatment of this autoimmune disease. Furthermore, all extracts were moderate inhibitors of $S$. pyogenes growth with MIC values $1000-1500 \mu \mathrm{g} / \mathrm{mL}$. S. pyogenes may cause a myriad of diseases including streptococcal pharyngitis, impetigo and rheumatic heart disease, depending on which tissue it infects. ${ }^{42,43}$ Thus, the methanolic L. longifolium, L. petersonii and M. alternifolia leaf extracts may also be useful in the prevention and treatment of these diseases.

Aside from inhibition of the growth of the bacterial triggers of the autoimmune disease discussed above, the L. longifolium, L. petersonii and $M$. alternifolia leaf extracts were also moderate to good inhibitors of several other bacterial pathogens. All extracts inhibited A. faecalis, A. hydrophilia, C. freundi and B. cereus growth, with MICs generally $<1000 \mu \mathrm{g} / \mathrm{mL}$. Thus, these extracts have potential in the treatment diseases caused by these pathogens (e.g. food poisoning, diarrhoea and dysentery). The L. longifolium and L. petersonii extracts were also good inhibitors of S. aureus and S. epidermidis growth (MICs $400-1000 \mu \mathrm{g} / \mathrm{mL}$ ). The $M$. alternifolia extract was a moderate inhibitor of the growth of these bacteria, with MICs $<3000 \mu \mathrm{g} / \mathrm{mL}$. As both of these bacteria are skin disease pathogens, these extracts also may have applications as topical treatments of these diseases.

Whilst an investigation of the phytochemistry of the methanolic L. longifolium, L. petersonii and M. alternifolia leaf extracts was beyond the scope of our study, previous studies have reported high terpenoid contents for essential oils of these species. ${ }^{7,15}$ Similarly, other plants of the family Myrtaceae are also well known for their high terpenoid contents.? Monoterpenes have been reported to exert a wide variety of biological effects including antibacterial, antifungal, anti-inflammatory and antitumour activities ${ }^{22}$ and therefore may contribute to the bacterial growth inhibitory activity of the L. longifolium, L. petersonii and M. alternifolia extracts reported in our study. A wide variety of monoterpenoids including camphor, carvone, cineole, borneol, menthone, pinene, terpinene, as well as their derivatives, inhibit the growth of an extensive panel of pathogenic and food spoilage bacteria. ${ }^{44}$ Interestingly, several of these monoterpenoids have also been reported to suppress NF- $\kappa B$ signaling (the major regulator of inflammatory diseases). ${ }^{45-48}$ This may be particularly relevant for the extracts which inhibited $P$. mirabilis (a bacterial trigger of rheumatoid arthritis) ${ }^{38,39}$ and $K$. pneumoniae (a trigger of ankylosing spondylitis). ${ }^{40,41}$ The terpene components in 

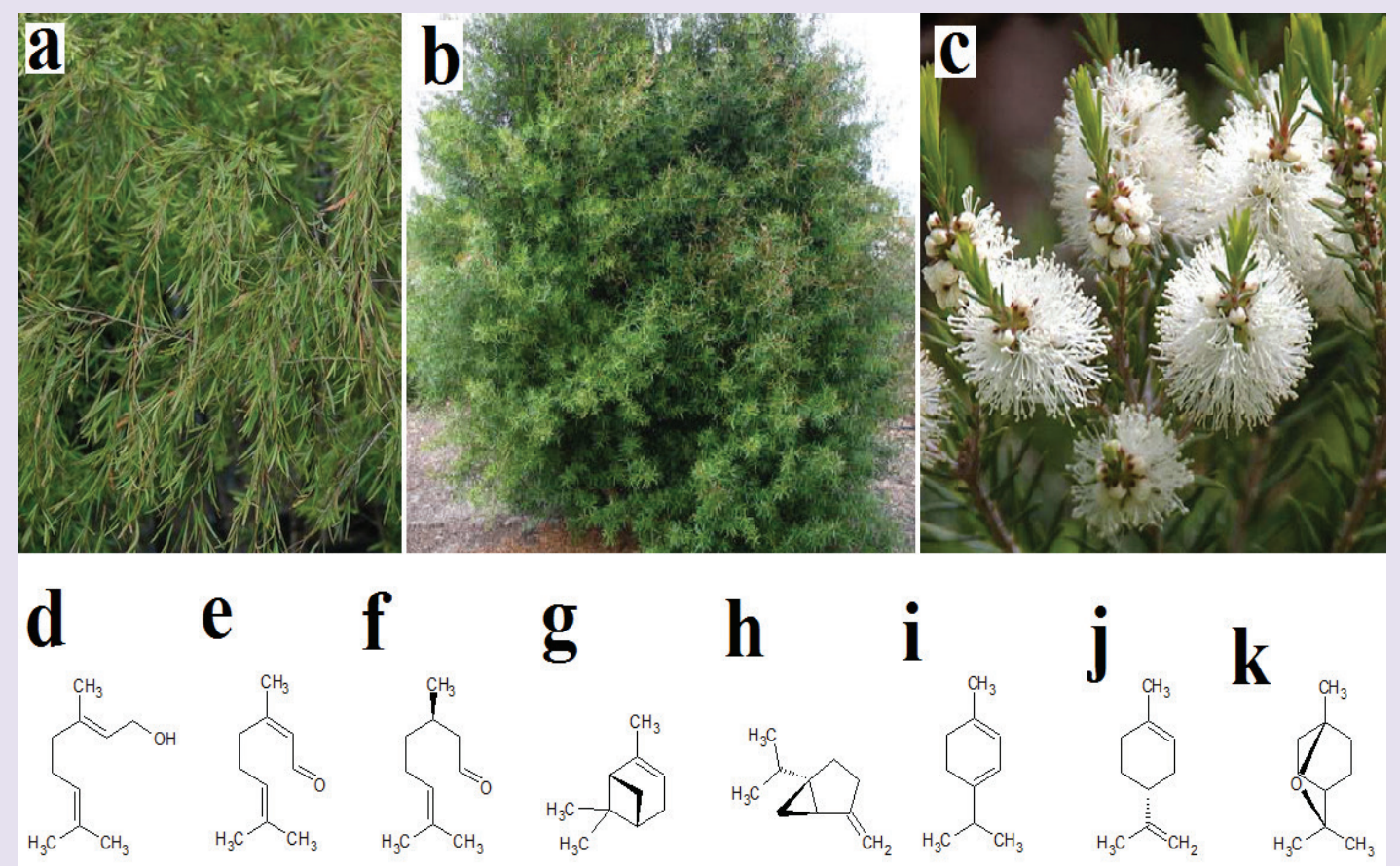

Figure 1: (a) L. longifolium, (b) L. petersonii, (c) M. alternifolia, (d) geraniol, (e) neral, (f) citronellal, (g) a-pinene, (h) sabinene, (i) a-terpinene, (j) limonene, (k) 1,8-cineole.

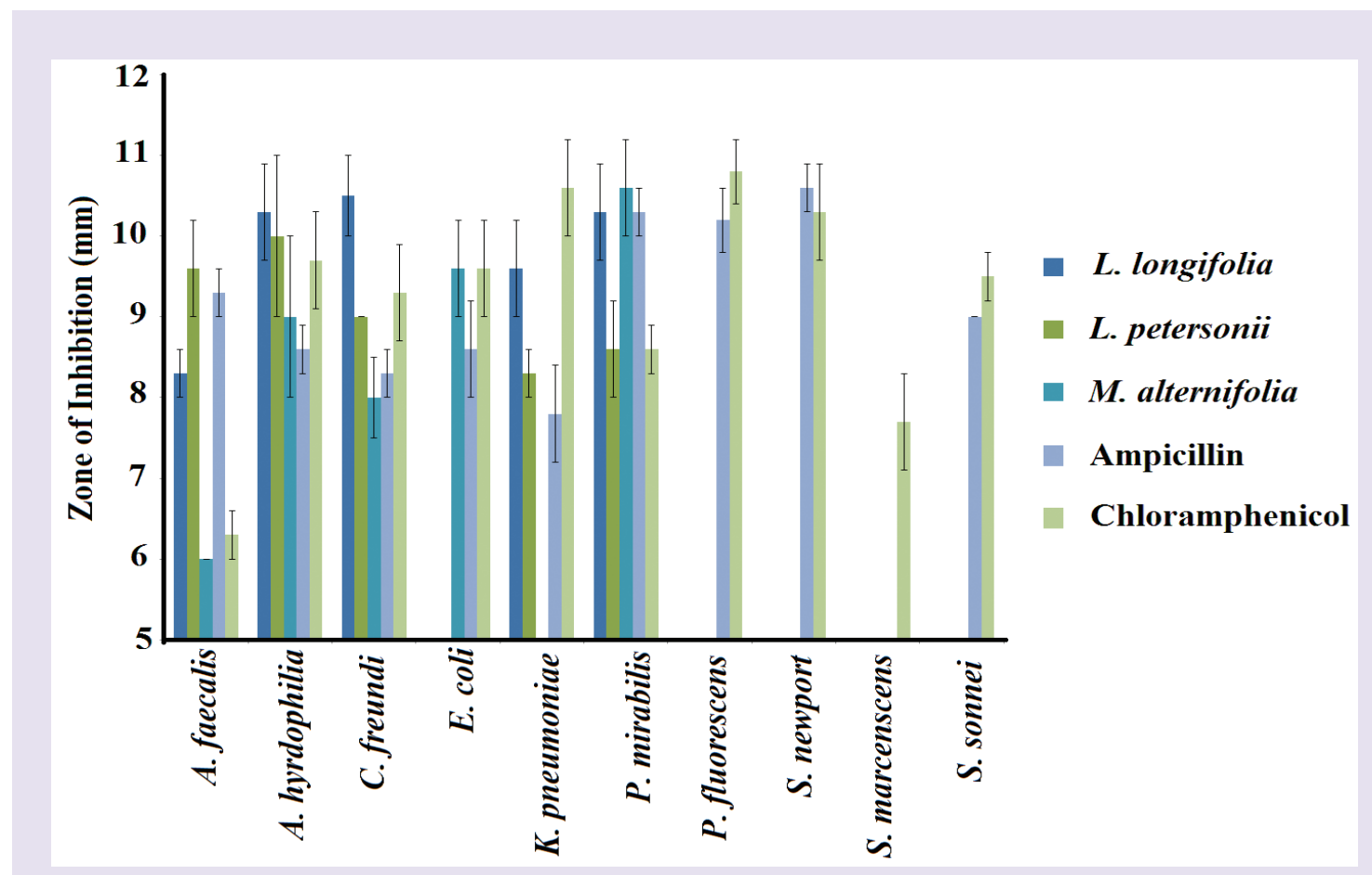

Figure 2: Growth inhibitory activity of the L. longifolium, L. petersonii and M. alternifolia leaf extracts against gram negative bacterial species and the ampicillin $(10 \mu \mathrm{g})$ and chloramphenicol $(2 \mu \mathrm{g})$ controls. All determinations were performed in at least triplicate and the results are expressed as mean zones of inhibition $(\mathrm{mm}) \pm \mathrm{SEM}$. 


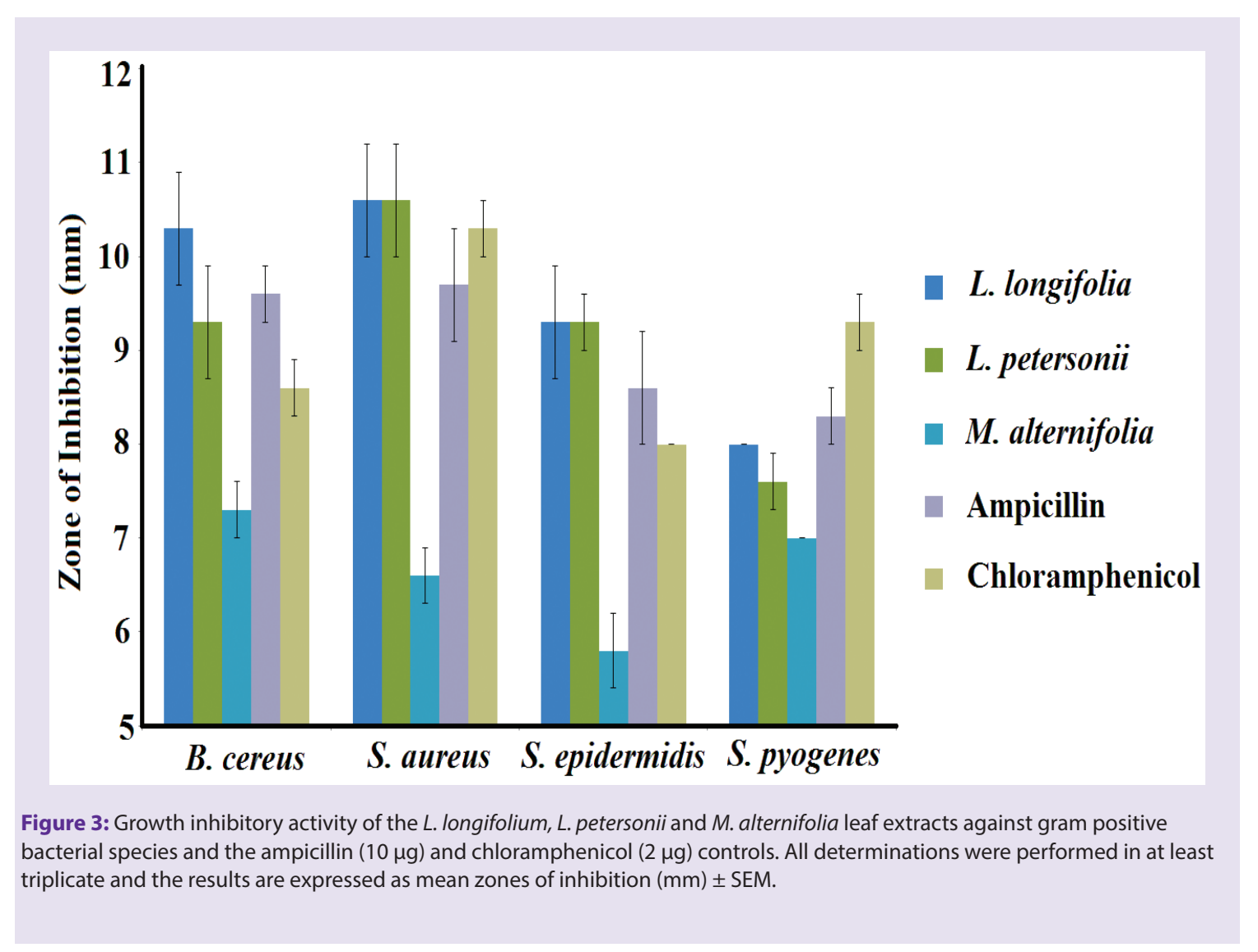

these extracts may therefore have a pleuripotent mechanism in blocking the autoimmune inflammatory diseases and relieving its symptoms by acting on both the initiator and downstream inflammatory stages of the disease. Further phytochemical evaluation studies and bioactivity driven isolation of active components is required to further evaluate the mechanism(s) of bacterial growth inhibition.

Another commonality between the inhibitory methanolic L. longifolium, L. petersonii and M. alternifolia leaf extracts was that all contained high levels of tannins (Table 1). Many studies have reported potent growth inhibitory activities for a number of tannin compounds. Gallotannins have been reported to inhibit the growth of a broad spectrum of bacterial species ${ }^{49}$ through a variety of mechanisms including binding cell surface molecules including lipotoichoic acid and proline-rich cell surface proteins, ${ }^{50,51}$ and by inhibiting glucosyltransferase enzymes. ${ }^{52}$ Elligitannins are also highly potent inhibitors of bacterial growth, with MIC values as low as $62.5 \mu \mathrm{g} / \mathrm{mL} .{ }^{49,51}$ Ellagitannins have also been reported to function via several antibiotic mechanisms including interaction with cytoplasmic oxidoreductases and by disrupting bacterial cell walls. ${ }^{49,51}$ Thus, it is likely that multiple compounds within the L. longifolium, $L$. petersonii and $M$. alternifolia leaf extracts may contribute to the inhibition of bacterial growth.

The findings reported here also demonstrate that the L. longifolium, L. petersonii and M. alternifolia leaf extracts were nontoxic towards Artemia franciscana nauplii, with $\mathrm{LC}_{50}$ values substantially $>1000 \mu \mathrm{g} / \mathrm{mL}$. Extracts with $\mathrm{LC}_{50}$ values $>1000 \mu \mathrm{g} / \mathrm{mL}$ towards Artemia nauplii are defined as being nontoxic. ${ }^{32}$ Whilst our preliminary toxicity studies indicate that these extracts may be safe for therapeutic use, studies using human cell lines are required to further evaluate the safety of these extracts. Furthermore, whilst these studies have demonstrated the potential of the L. longifolium, L. petersonii and M. alternifolia leaf extracts in the development of future antibiotic chemotherapeutics for the prevention and treatment of urinary tract infections, autoimmune diseases (particularly rheumatoid arthritis and ankylosing spondylitis) and some skin diseases, more work is required to isolate the inhibitory components and determine the mechanism(s) of inhibition.

\section{CONCLUSION}

The results of this study demonstrate the potential of the L. longifolium, L. petersonii and M. alternifolia leaf extracts as inhibitors of pathogenic bacteria growth. Furthermore, their lack of toxicity indicates than they may be safe for internal as well as topical treatment in the doses tested. Further studies aimed at the purification and identification of bioactive components are needed to examine the mechanisms of action of these agents.

\section{ACKNOWLEDGEMENTS}

The authors are grateful to Philip Cameron for providing the L. longifolium, L. petersonii and M. alternifolia leaf leaves used in this study, and to Michelle Mendell and Jane Gifkins for the gift of the bacterial strains. Financial support for this work was provided by the Environmental Futures Research Institute and the School of Natural Sciences, Griffith University, Australia.

\section{CONFLICTS OF INTEREST}

The authors report no conflicts of interest.

\section{ABBREVIATIONS USED}

DMSO: Dimethyl sulfoxide; $\mathbf{L C}_{50}$ : The concentration required to achieve $50 \%$ mortality; MIC: minimum inhibitory concentration. 

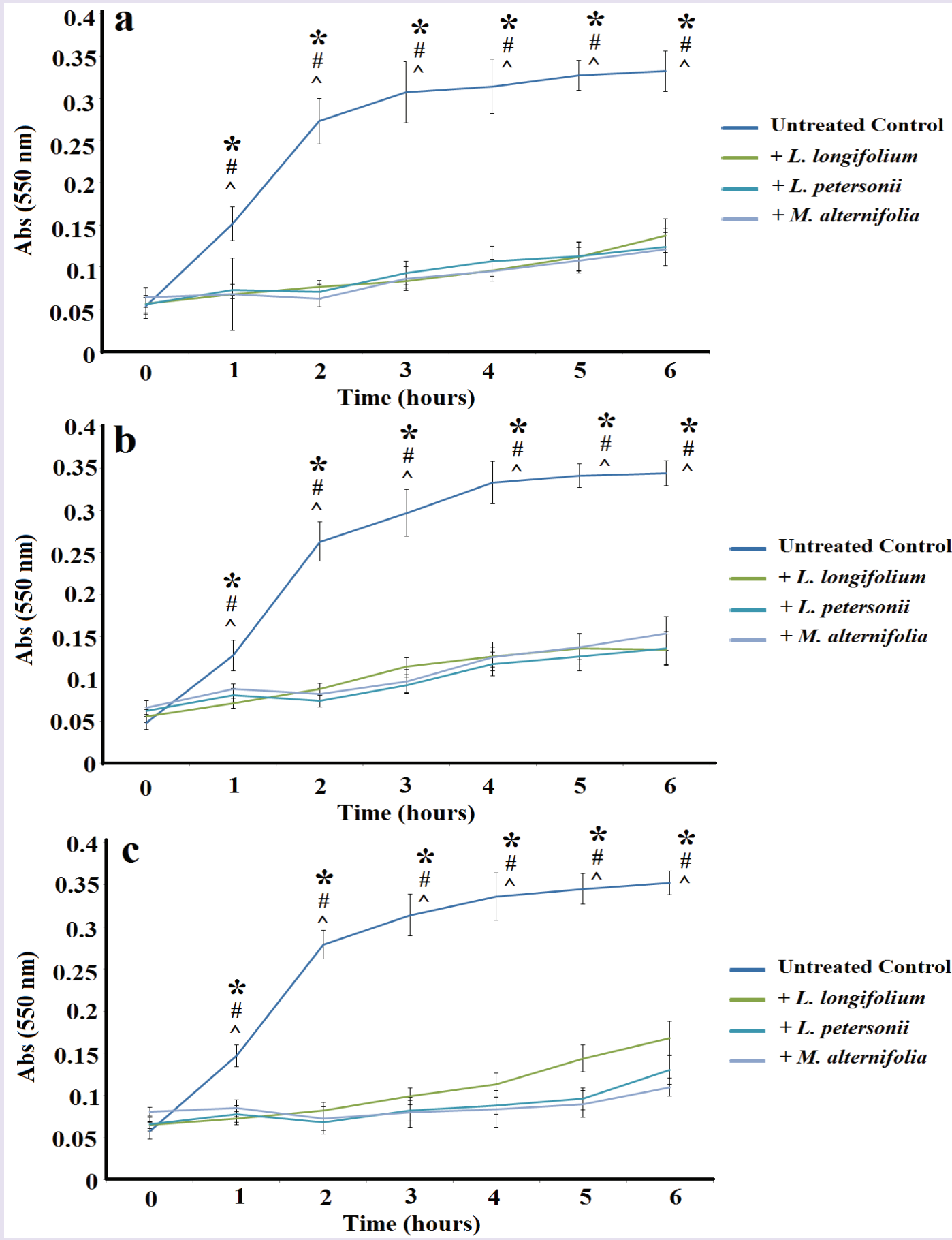

Figure 4: Bacterial growth curves for (a) A. hydrophilia, (b) C. freundi, (c) P. mirabilis. All bioassays were performed in at least triplicate and are expressed as mean \pm SEM. ${ }^{*}=$ growth results in the presence of $L$. longifolium extract that are significantly different to the untreated control growth $(p<0.01) ; \#=$ growth results in the presence of $L$. petersonii extract that are significantly different to the untreated control growth $(p<0.01) ; \wedge=$ growth results in the presence of $M$. alternifolia extract that are significantly different to the untreated control growth $(p<0.01)$. 


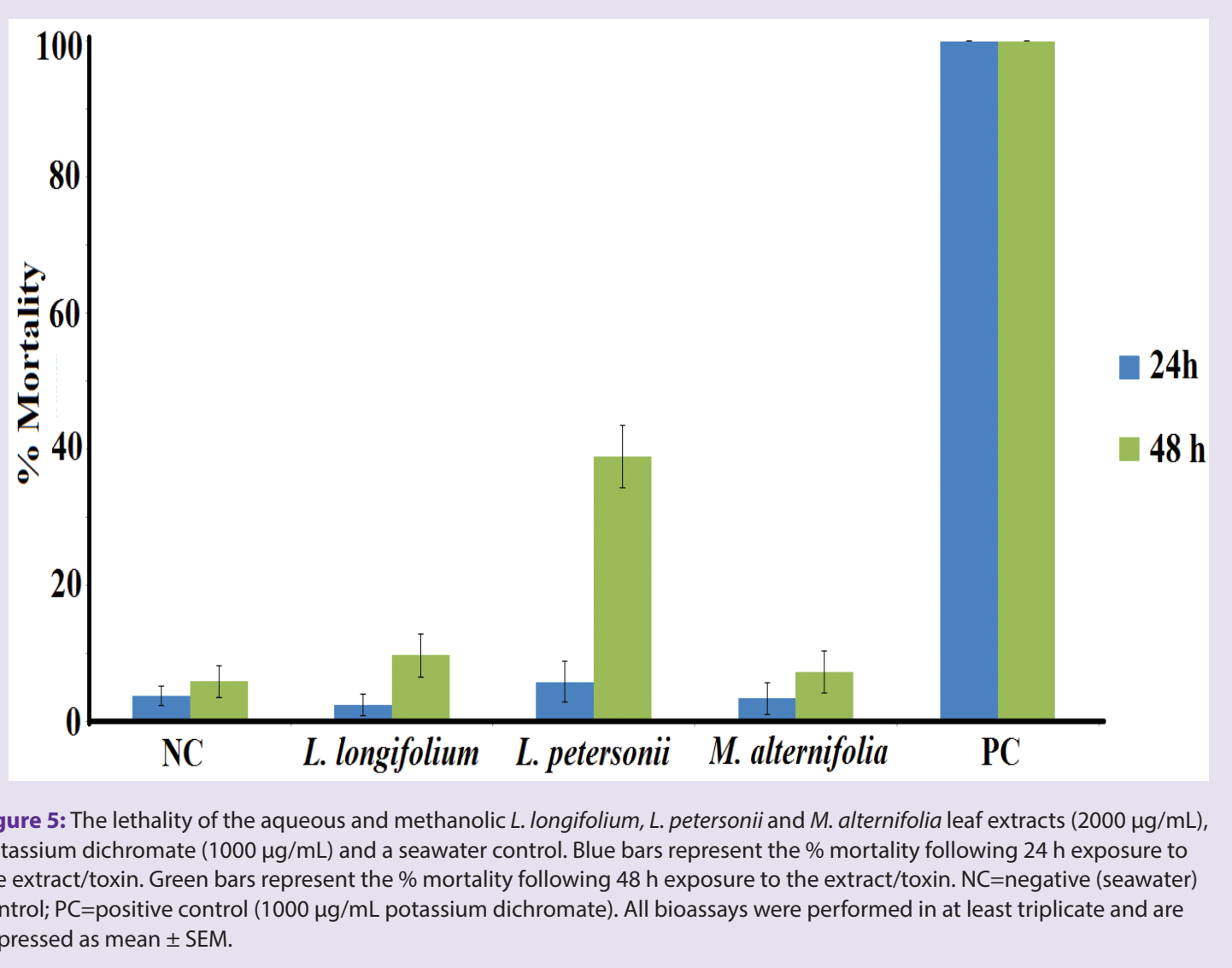

\section{REFERENCES}

1. Cowan MM. Plant products as antibacterial agents. Clinical Microbiology Reviews. 1999;12(4):564-82.

2. Bhavnani SM, Ballow $\mathrm{CH}$. New agents for Gram-positive bacteria. Current Opinion in Microbiology. 2000;3(5):528-34.

3. Chiariandy $\mathrm{CM}$, Seaforth $\mathrm{CE}$, Phelps $\mathrm{RH}$. Screening of medicinal plants from Trinidad and Tobago for antimicrobial and insecticidal properties. Journal of Ethnopharmacology. 1999;64(3):265-70.

4. Patwardhan B, Warude D, Pushpangadan P. Ayurveda and traditional Chinese medicine: a comparative overview. Evidence-based Complimentary and Alternative Medicine. 2005;2(4):465-73.

5. Hostettmann K, Marston A, Ndjoko K. The potential of African plants as a source of drugs. Current Organic Chemistry. 2000;4(10):973-1010.

6. Paz EA, Cerdeiras MP, Fernandez J. Screening of Uruguayan medicinal plants for antimicrobial activity. Journal of Ethnopharmacology. 1995;45(1):67-70.

7. Cock IE. Medicinal and aromatic plants-Australia. In Ethnopharmacology, Encyclopedia of Life Support Systems (EOLSS), 2011. Developed under the auspices of UNESCO. Oxford, UK: EOLSS Publishers; 2011. Available from: http://www. eolss.net. Accessed 1 April 2013.

8. Cock IE. Antimicrobial activity of Callistemon citrinus and Callistemon salignus methanolic extracts. 2012 Pharmacognosy Communications. 2012;2(3):50-7. DOI: $10.5530 /$ pc.2012.3.11

9. Wright $\mathrm{MH}$, Matthews $\mathrm{B}$, Arnold MSJ et al. The prevention of fish spoilage by high antioxidant Australian culinary plants: Shewanella putrefaciens growth inhibition. International Journal of Food Science and Technology 2016; DOI: 10.1111/ijfs. 13026

10. Cock IE. Antimicrobial activity of Leptospermum bracteata and Leptospermum juniperium methanolic extracts. Pharmacognosy Communications. 2013; 3(3):45-52. DOI: 10.5530/pc.2013.3.9

11. Cock IE. Antibacterial activity of selected Australian plant species. The Internet Journal of Microbiology. 2008;6:2.

12. Sautron C, Cock IE. Antimicrobial activity and toxicity of Syzygium australe and Syzygium leuhmanii fruit extracts. Pharmacognosy Communications. 2014;4(1):53-60. DOI: 10.5530/pc.2014.1.8

13. Chikowe G, Mpala L, Cock IE. Antibacterial activity of selected Australian Syzygium species. Pharmacognosy Communications. 2013;3(4):77-83. DOI: 10.5530/pc.2013.4.11
14. Cock IE. Antimicrobial activity of Syzygium australe and Syzygium leuhmannii methanolic extracts. Pharmacognosy Communications. 2012;2(2):71-7. DOI: 10.5530/pc.2012.2.11

15. Webb MA. Bush Sense. Australian Essential oils and aromatic compounds. Griffin Press, 2000, Adelaide Australia.

16. Opdyke DLJ. Citral. Monographs on fragrance raw materials. Food and Cosmetics Technology. 1976;14:615.

17. Wilkinson JM, Hipwell M, Ryan T. Bioactivity of Backhousia citriodora: antibacterial and antifungal activity. Journal of Agriculture and Food Chemistry. 2003;51(1):76-81.

18. Inouye S, Takizawa T, Yamaguchi H. Antimicrobial activity of essential oils and their major constituents against respiratory tract pathogens by gaseous contact. Journal of Antimicrobial Chemotherapy. 2001;47(5):565-73.

19. Kim JM, Marshall MR, Cornell JA. Antibacterial activity of carvacrol, citral and geraniol against Salmonella typhimurium in culture media and in fish cubes. Journal of Food Science. 1995;60(6):1364-8.

20. Griffin SG, Markham JL, Leach DN. An agar dilution method for the determination of the minimum inhibitory concentration of essential oils. Journal of Essential Oil Research. 2000;12(2):249-55.

21. Hammer KA, Carson CF, Riley TV. Antimicrobial activity of essential oils and other plant extracts. Journal of Applied Microbiology. 1999;86(6):985-90.

22. Cock IE. The phytochemistry and chemotherapeutic potential of Tasmannia lanceolata (Tasmanian pepper): A review. Pharmacognosy Communications. 2013;3(4):1-13. DOI: 10.5530/pc.2013.4.3

23. Kalt FR, Cock IE. Gas chromatography-mass spectroscopy analysis of bioactive Petalostigma extracts: Toxicity, antibacterial and antiviral activities. Pharmacognosy Magazine. 2014;10(37 Supp):S37-S49. DOI: 10.4103/0973-1296.127338

24. Vesoul J, Cock IE. The potential of Bunya nut extracts as antibacterial functional foods. Pharmacognosy Communications. 2012;2(1):72-9. DOI: 10.5530/pc.2012.1.3

25. Hart C, Ilanko P, Sirdaarta J, et al. Tasmannia stipitata as a functional food/natural preservative: Antimicrobial activity and toxicity. Pharmacognosy Communications. 2014;4(4):33-47. DOI: 10.5530/pc.2014.4.4

26. Winnett $\mathrm{V}$, Boyer $\mathrm{H}$, Sirdaarta J, et al . The potential of Tasmannia lanceolata as a natural preservative and medicinal agent: Antimicrobial activity and toxicity. Pharmacognosy Communications. 2014;4(1):42-52. DOI: 10.5530/pc.2014.1.7

27. Arkhipov A, Sirdaarta J, Rayan P, et al. An examination of the antibacterial, antifungal, anti-Giardial and anticancer properties of Kigelia africana fruit extracts Pharmacognosy Communications. 2014;4(3):62-76. DOI: 10.5530/pc.2014.3.7 
28. Courtney R, Sirdaarta J, Matthews B, et al. Tannin components and inhibitory activity of Kakadu plum leaf extracts against microbial triggers of autoimmune inflammatory diseases. Pharmacognosy Journal. 2015;7(1):18-31. DOI: 10.5530/ pj.2015.7.2

29. Sirdaarta J, Matthews B, Cock IE. Kakadu plum fruit extracts inhibit growth of the bacterial triggers of rheumatoid arthritis: Identification of stilbene and tannin components. Journal of Functional Foods. 2015;17:610-20. DOI: 10.1016/j.ff.2015.06.019

30. Cock IE. Antimicrobial activity of Acacia aulacocarpa and Acacia complanta methanolic extracts. Pharmacognosy Communications. 2012;2(1):66-71. DOI: 10.5530/pc. 2012.1 .12

31. Ruebhart DR, Wikramasinghe WA, Cock IE. Protective efficacy of the antioxidants vitamin $\mathrm{E}$ and Trolox against Microcystis aeruginosa and microcystin-LR in Artemia franciscana nauplii. Journal of Toxicology and Environmental Health Part A. 2009;72(24):1567-75.

32. Cock IE, Ruebhart DR. Comparison of the brine shrimp nauplii bioassay and the ToxScreen-II test for the detection of toxicity associated with Aloe vera (Aloe barbadensis Miller) leaf extract. Pharmacognosy Research. 2009;1(2):98-101.

33. Cock IE. Assessment of the toxicity of selected Australian native plant extracts using the Artemia franciscana nauplii bioassay. The Internet Journal of Toxicology. 2008;5:2.

34. Mohanty S, Cock IE. Evaluation of the antibacterial activity of Mycaria caulifloria methanolic leaf and fruit extracts. The Internet Journal of Microbiology. $2009 ; 7(2)$.

35. Cock IE, van Vuuren SF. South African food and medicinal plant extracts as potential antimicrobial food agents. Journal of Food Science and Technology. 2015;52(11):6879-99. DOI: 10.1007/s13197-015-1806-3

36. Cock IE, Kukkonen L. An examination of the medicinal potential of Scaevola spinescens: Toxicity, antibacterial, and antiviral activities. Pharmacognosy Research. 2011;3(2):85-94. DOI: 10.4103/0974-8490.81955

37. Vesoul J, Cock IE. An examination of the medicinal potential of Pittosporum phylliraeoides: Toxicity, antibacterial, and antifungal activities. Pharmacognosy Communications. 2011;1(2):8-17. DOI: 10.5530/pc.2011.2.1

38. Cock IE, van Vuuren SF. Anti-Proteus activity of some South African plants: Their potential for the prevention of rheumatoid arthritis. Inflammopharmacology. 2014;22(1):23-36. DOI: 10.1007/s10787-013-0179-3

39. Ebringer A, Rashid T. Rheumatoid arthritis is an autoimmune disease triggered by Proteus urinary tract infection. Clinical and Developmental Immunology. 2006;13(1):41-8.
40. Cock IE, van Vuuren SF. The potential of selected South African plants with antiKlebsiella activity for the treatment and prevention of ankylosing spondylitis. Inflammopharmacology. 2015;23(1):21-35. DOI: 10.1007/s10787-014-0222-z

41. Ebringer A, Rashid T, Wilson C. Ankylosing spondylitis as an auto-immune disease linked to intestinal Klebsiella infection: prospects for a new therapeutic approach. Current Rheumatology Reviews. 2006;2:55-68.

42. Gerber MA, Baltimore RS, Eaton CB. Prevention of rheumatic fever and diagnosis and treatment of acute Streptococcal pharyngitis. A scientific statement from the American Heart Association Rheumatic Fever, Endocarditis, and Kawasaki Disease Committee of the Council on Cardiovascular Disease in the Young, the Interdisciplinary Council on Functional Genomics and Translational Biology, and the Interdisciplinary Council on Quality of Care and Outcomes Research: Endorsed by the American Academy of Pediatrics. Circulation. 2009;119(11):1541-51.

43. Wright MH, Arnold MSJ, Lee CJ, et al. Qualitative phytochemical analysis and antibacterial activity evaluation of Indian Terminalia spp. against the pharyngitis causing pathogen Streptococcus pyogenes. Pharmacognosy Communications. 2016;6(2):85-92. DOI: 10.5530/pc.2016.2.6

44. Bakkali F, Averbeck S, Averbeck D. Biological effects of essential oils - A review Food and CXhemical Toxicology. 2008;46(2):446-75.

45. Salminen A, Lehtonen M, Suuronen T. Terpenoids: Natural inhibitors of NF- $\kappa B$ signalling with anti-inflammatory and anticancer potential. Cell and Molecular Life Sciences. 2008;65(19):2979-99.

46. Lu XG, Zhan LB, Feng BA. Inhibition of growth and metastasis of human gastric cancer implanted in nude mice by d-limonene. World Journal of Gastroenterology. 2004; 10(14):2140-4.

47. Crowell PL. Prevention and therapy of cancer by dietary monoterpenes. Journal of Nutrition. 1999;129(3):775S-8S.

48. Zhou JY, Tang FD, Mao GG. Effect of a-pinene on nuclear translocation of NF-kB in THP-1 cells. Acta Pharmacologica Sinica. 2004;25(4):480-4.

49. Buzzini P, Arapitsas P, Goretti M. Antimicrobial activity of hydrolysable tannins Mini-Reviews in Medicinal Chemistry. 2008;8:1179-87.

50. Wolinsky LE, Sote EO. Isolation of natural plaque-inhibiting substances from 'Nigerian chewing sticks'. Caries Research. 1984;18(3):216-25.

51. Hogg SD, Embery G. Blood-group-reactive glycoprotein from human saliva interacts with lipoteichoic acid on the surface of Streptococcus sanguis cells. Archives in Oral Biology. 1982;27(3):261-8.

52. Wu-Yuan CD, Chen CY, Wu RT. Gallotannins inhibit growth, water-soluble glucan synthesis, and aggregation of Streptococci mutans. Journal of Dental Research. 1988;67(1):51-5. 
PICTORIAL ABSTRACT
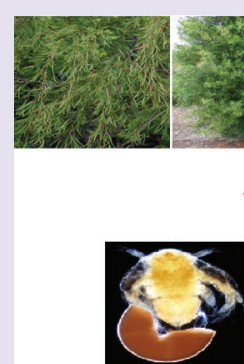

Non-Toxic

Bacteria

Bacteria

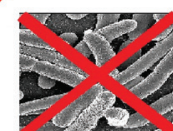

\section{SUMMARY}

- L. longifolium, L. petersonii and M. alternifolia extracts displayed broad spectrum antibacterial activity against gram positive and gram negative bacteria.

- All extracts were potent inhibitors of P. mirabilis growth, with MICs generally $<500 \mu \mathrm{g} / \mathrm{mL}$.

- A. hydrophilia, C. freundi, and B. cereus were also particularly susceptible (MICs as low as $147 \mu \mathrm{g} / \mathrm{mL}$ )

- All L. longifolium, L. petersonii and M. alternifolia extracts were nontoxic.

\section{ABOUT AUTHORS}

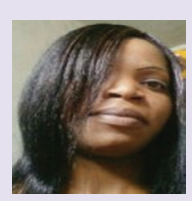

Ms Lindiwe Mpala completed at BSc at Griffith University in life sciences. Following graduation, she undertook a research project in Dr lan Cock's laboratory in the School of Natural Sciences at Griffith University. The project examined the growth inhibitory properties of a variety of Australian native plants against an extensive panel of bacterial pathogens.

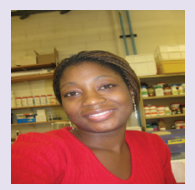

Ms Getmore Chikowe completed at BSc at Griffith University in life sciences. Following graduation, she undertook a research project in Dr lan Cock's laboratory in the School of Natural Sciences at Griffith University. The project examined the growth inhibitory properties of a variety of Australian native plants against an extensive panel of bacterial pathogens.

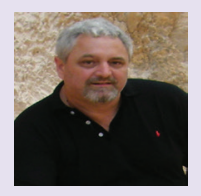

Dr lan Cock leads a research team in the Environmental Futures Research Institute and the School of Natural Sciences at Griffith University, Australia. His research involves bioactivity and phytochemical studies into a variety of plant species of both Australian and international origin, including Aloe vera, South Asian and South American tropical fruits, as well as Australia plants including Scaevola spinescens, Pittosporum phylliraeoides, Terminalia ferdinandiana (Kakadu plum), Australian Acacias, Syzygiums, Petalostigmas and Xanthorrhoea johnsonii (grass trees). This range of projects has resulted in nearly 200 publications in a variety of peer reviewed journals. 